\title{
New Record of Exotic Fish Red Bellied Pacu, Piaractus Brachypomus (Cuvier, 1818) From Vellayani Fresh Waterlake, Southwest Coast Of India
}

\author{
Reenamole, G.R ${ }^{1}$, George D'cruz, $\mathbf{F}^{\mathbf{2}}$ \\ ${ }^{1,2}$ Department Of Zoology, Zoology Research Centre, Fatima Mata National College, Kollam, University Of Kerala, Thiruvananthapuram- \\ 695581, India
}

\begin{abstract}
This paper documents the first record of the occurrence of the exotic South American fish Red Bellied Pacu related to the piranhas, in Vellayani Freshwater Lake at Thiruvananthapuram district, Kerala, the southern part of Western Ghats region. The morphological taxonomy revealed that the specimen is Piaractus brachypomus (Machado-Allison 1982; Goulding and Carvalho 1982; Ruiz-Carus and Davis 2003) of the subfamily Serrasalmidae (Pacus and Piranhas) of family Characidae. The preliminary investigation revealed that Pacu, one of the preferred aquarium fishes, might have reached the lake accidently and established a viable population. Though not fierce and deadly like piranhas, the adult pacus being omnivores feeding on fishes, it rings alarm bells of danger to the 42 species of already existing fish populations (Bijukumar et. al, 2013) in Vellayani Lake, the second largest fresh water lake in Kerala.
\end{abstract}

Keywords: Red bellied pacu, Characidae, Serrasalmidae, Piaractus brachypomus, Vellayani Freshwater Lake

\section{Introduction}

There are so many reports of introduction of exotic species causing numerous negative effects to biodiversity, natural environment, economy and even human health. Often the exotic species become predators or competitors of native species (Hill AM, DM Lodge, 1999). The ornamental fish trade spread all over the world has already become a route to exotic fish introduction to indigenous natural habitats, and it is reported that one third of the world's worst aquatic invasive species are ornamental fishes (Padilla and Williams, 2004). Red Bellied Pacu is an appreciated food fish which led the Brazilian Government to set up a breeding programme for the species to replenish the wild population. The project was successful and this has led to Red Bellied Pacu becoming the absolutely most common Pacu in the aquarium trade.

Introductions of Red Bellied Pacu populations have been reported in many regions around the globe, in places as unlikely as Vancouver, British Columbia, etc. This South American native fish was found near Yuma, Arizona in June 2006 and in New Jersy in June 2015 (Brian Clark Howard, 2012). Zeb Hogan of University of Nevada, Reno (2007) has reported the occurrence of pacu in Denmark, Michigan and other places and opined that these fishes are not dangerous to humans. However, there is a report from Papua New Guinea in 2011, of two human deaths due to Pacu attack by biting off the testicles of fishermen (Rick Spilman, 2013).

Red Bellied Pacus were introduced to India sometime between 2003 and 2004 from Bangladesh and have become the focus of several aquaculture projects. (Innes, 1966; Hanke, et al., 2006; Ramirez-Duarte, et al., 2008; Chattarje and Mazumdar, 2009; Froese and Pauly, 2010; Nascimento, et al., 2010). In 2011, Unmesh Katwate et.al angled a huge pomfret like silvery fish from Gadhi River in Panvel,
Maharashtra the northern Western Ghats region, which was later identified as Red Bellied Pacu, Piaractus brachypomus. From the main river channel eight more $P$. brachypomus were subsequently collected by the same team.

In Kerala, recently, this fish was recorded from Periyar River. Researchers from National Board of Fish Genetic Research, Kochi had identified the fish caught from natural waters of the Periyar and Chalakkudy Rivers as Pacu in 2011. Many bio-invasions have been recorded in Kerala, which is part of the Western Ghats biodiversity hot spot. The new competitors in the race for survival in the Western Ghats region are piranhaes relatives. According to the ornamental fish vendors Pacu, Piranha and the related groups are supplied to the city aquaria from neighbouring states by the wholesalers. In Kerala, the local ornamental fish vendors also culture these fishes in ponds.

This paper documents the invasion of $P$. Brachypomus in the Vellayani Freshwater Lake in the valleys of Southern Western Ghats in Thiruvananthapuram district of Kerala, and the challenges faced by the biodiversity of the lake, especially the ichthyofauna.

\section{Materials and Methods}

\subsection{Study Area and Sample Collection}

The fish was collected from Vellayani Freshwater Lake $\left(8^{\circ}\right.$ $24^{\text {ce }} 09^{\prime \prime}-8^{\circ} 26^{\text {ec }} 30^{\prime \prime} \mathrm{N}$ and $\left.76^{\circ} 59^{\text {"e }} 08^{\prime \prime}-76^{\circ} 59^{\text {ec }} 47^{\prime \prime} \mathrm{E}\right)$ Thiruvananthapuram Distrct in Kerala (Fig. 1), located 19 $\mathrm{km}$ away from Thiruvananthapuram city. The lake is situated 29 meters above mean sea level with a length of $3.15 \mathrm{~km}$ and width of $1 \mathrm{~km}$. The depth varies from 2 to $6 \mathrm{~m}$. 


\section{International Journal of Science and Research (IJSR) \\ ISSN (Online): 2319-7064}

Index Copernicus Value (2013): 6.14 | Impact Factor (2014): 5.611

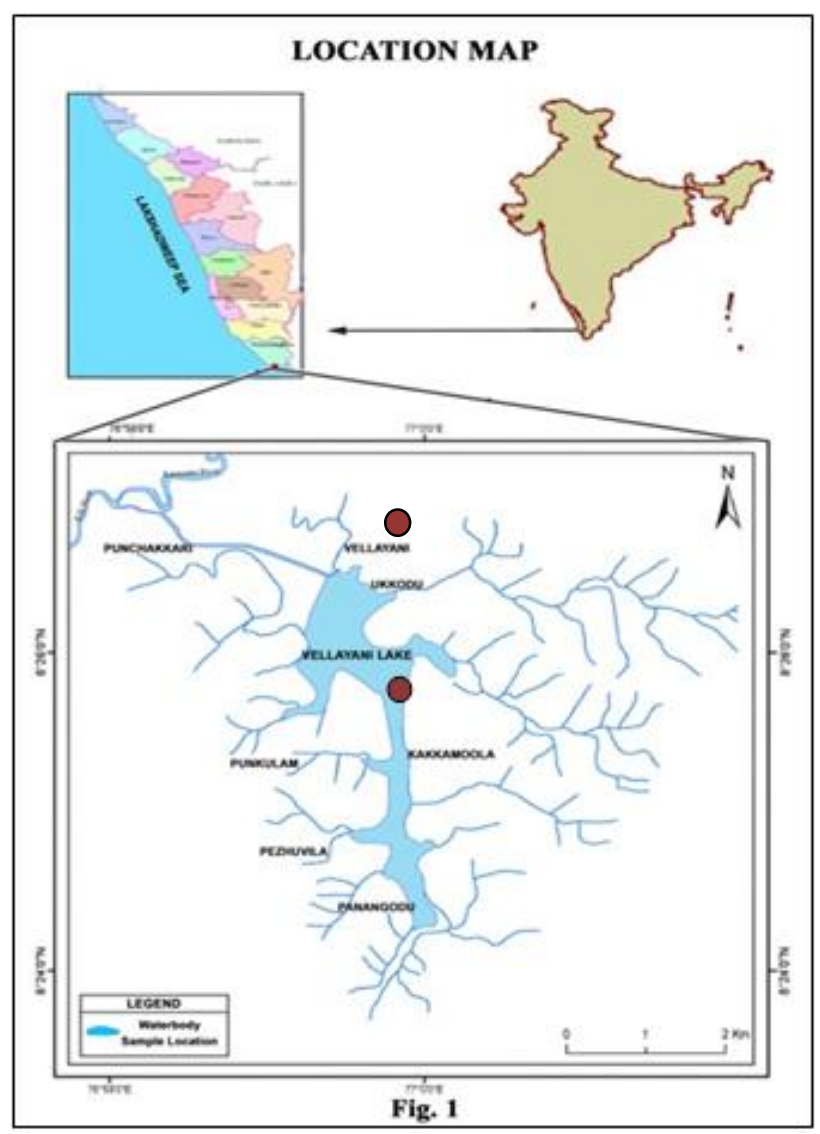

Figure 1: Red spot represents the region of the Lake from where Red Bellied Pacu was caught.

During a fish biodiversity survey of the Lake (June 2013 to May 2016), a Red Bellied Pacu was observed among the catch on 3-11-2015. „Pattu Valae, a type of seine net was used for the collection of the fish during night. The specimen was brought to the Laboratory for taxonomic identification. Previously published descriptions available from the internet were used to ascertain whether the fish was Pacu or Piranha. Further identification up to species level was carried out using the distinguishing characteristics provided by Machado-Allison, 1982; Goulding and Carvalho, 1982; Ruiz-Carus and Davis, 2003. The identified specimen is preserved at the Laboratory of Fatima Mata National College, Kollam, under the University of Kerala.

\section{Results and Discussions}

Red Bellied Piranha (Pygocentrus nattereri) is the world's most misunderstood fish with regard to identity. Red Bellied Pacus are often mistaken for piranhas. Pacus and Piranhas together form a family known as the Serrasalmidae, which in some references is still referred to as the subfamily Serrasalminae, under the family Characidae. Though Pacu is nearly identical to the fierce and deadly Piranha, it is a peaceful omnivore. These fishes have many similarities in both appearance and behavior.

The sample fish was confirmed as Red bellied Pacu and not Red Bellied Piranha, based on the following characters, as per the descriptions of Machado-Allison (1982) and Froese and Pauly (2010).

- Red Bellied Pacu can be distinguished from piranhas primarily by dentition. Single row of serrated incisor-like teeth is present in piranhas, but two rows of molariform teeth in Pacus (Fig.3 and4). In the sample specimen, there were two rows of hard, flattened teeth (the inner row is not completely developed, as the specimen was juvenile). This dentition is comprised of 2 series of molariform incisors located on the premaxilla and 1 row of dentary teeth.

- Piranha is smaller species reaching around six inches (about fifteen centimetres). Pacu are generally very large fish and are exceeding two feet (sixty centimetres). The sample fish obtained measured a standard length of 20 centimetres (more than 15 centemetres).

- As juveniles, Red Bellied Pacu mimics Piranha by displaying dark grey to black spots on the body, a standard characteristic of piranha. The sample specimen possesses the same spots, showing that it is a juvenile Pacu. According to Froese and Pauly (2010), as Pacu reaches adulthood, the spots disappear.

The sample specimen Red Bellied Pacu (Fig.2) was identified as Piaractus brachypomus (Cuvier 1818), native of the Amazon and Orinoco river basins in tropical South America as per the distinguishing characteristics provided by Goulding and Carvalho, 1982; Innes, 1966; Schleser, 1997; Ross, 2001; Sakamoto, et al., 2001; Ruiz-Carus and Davis, 2003; Lovera, 2005; Nascimento, et al., 2010. Red Bellied Pacus form a single genus Piaractus. There are two recognised species in the genus, namely $P$. Brachipomus and P. Mesopotamicus. The sample specimen was identified as P. Brachipomus, based on the following characters.

- Spotted body (juvenile)

- Fins are dark edged (juvenile)

- A distinctive large blotch on the opercle (Fig.2)

- Larger number of lateral scales compared to $P$. Mesopotamicus $(<110)-119$

- The body is deep and laterally compressed, with silvery sides (becoming darker approaching the dorsum) and red coloration on the belly, chin, pectoral fins, and the leading rays of the anal fin. The remaining rayed fins are uniformly dark-coloured.

- A small, unrayed adipose fin is present approximately midway between the dorsal and caudal fins (Fig.2).

- The dorsal fin has 18 rays, the pectoral fins 16 , the anal fin 27 , and the pelvic fins 8 . The first few rays of the dorsal and anal fins are longer than the remaining elements.

- A row of sharp serrae formed by modified scales is found on the abdomen.

\section{Scientific Classification}

Kingdom : Animalia

Phylum : Chordata

Class : Actinopterygii

Order : Characiformes

Family : Characidae

Subfamily : Serrasalmidae

Genus : Piaractus

Species : P. brachypomus

Binomial name : Piaractus brachypomus (Cuvier, 1818)

\section{Volume 4 Issue 12, December 2015}




\section{International Journal of Science and Research (IJSR) \\ ISSN (Online): 2319-7064 \\ Index Copernicus Value (2013): 6.14 | Impact Factor (2014): 5.611}

Synonyms : Colossoma bidens (Spix and Agassiz 1829), C.brachypomum (Cuvier 1818), Myletes paco Humboldt 1821.

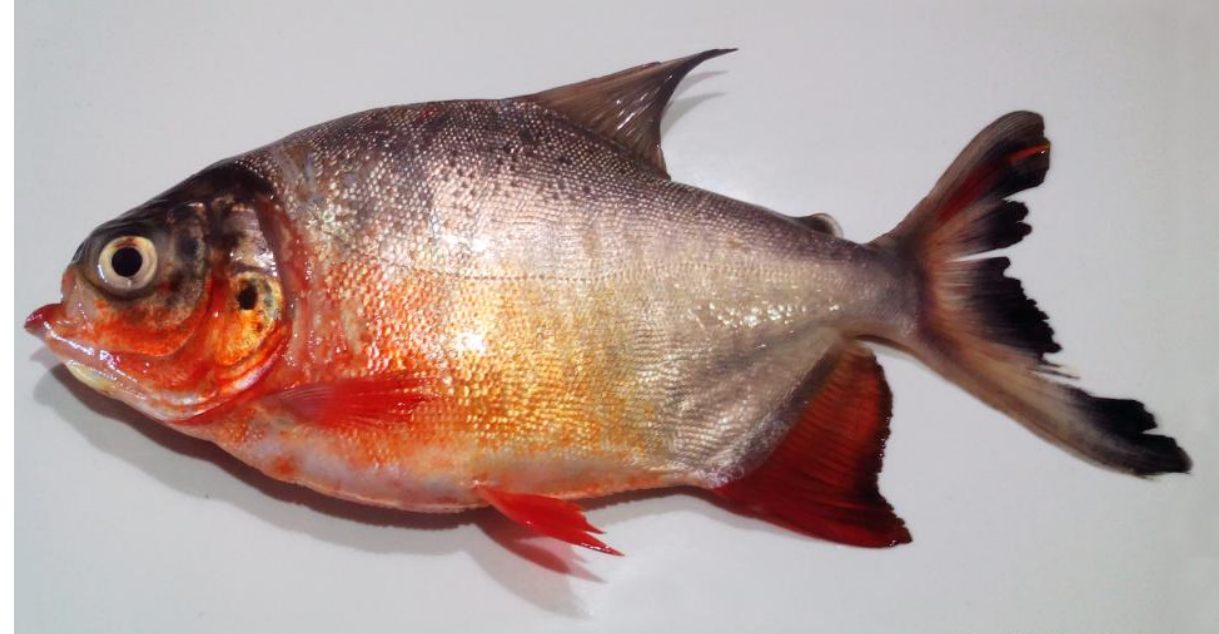

Figure 2: Red- Bellied Pacu (Piaractus brachypomus Cuvier, 1818) from Vellayani Fresh water Lake

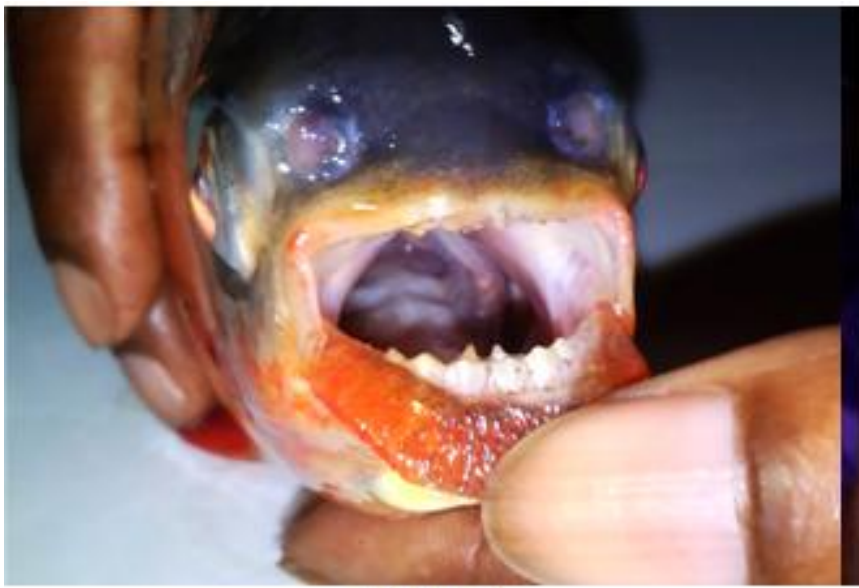

Figure 3

Figure 4

Figure 3 and Figure 4: Molariform (human teeth-like) teeth in Piaractus brachypomus (Cuvier, 1818)

Common names for this species vary by region. It is known as ,pirapitinga ${ }^{e e}$ in Brazil, ,paco ${ }^{e}$ in Peru and ,cachama blanca $^{\text {ee }}$ in Colombia (Innes, 1966; Hanke, et al., 2006; Ramirez-Duarte, et al., 2008; Chattarje and Mazumdar, 2009; Froese and Pauly, 2010; Nascimento, et al., 2010).

In aquarium, Pacus are omnivores and require a diet of both high protein and vegetable matter. Cichlid pellets and koi pellets are the common food items given by aquarists. To provide protein, fish, worms, and fish meat are also given. In the wild, Pacus eat a variety of foods. The main part of their diet consists of fruits, nuts and seeds. The teeth of Pacu are adapted for cracking open the hard shells of nuts and seeds. Despite being mostly vegetarian during the growth period, the adults will feed on smaller animals such as insects, smaller fish and even mammalian body parts, as pointed by gut content analysis of Red Bellied Pacu from the SepikRamu River Basin, Papua New Guinea (Sandra Bibiana Correa et al., 2015). The stomach content analysis of Red Bellied Pacu revealed that the main food was plants or detritus matters and fruits as per the above mentioned study. They also feed on zooplankton, insects, snails and decaying plants. Due to the presence of powerful dentition they can crush hard food and cause serious bites (Arsenia G.2007).
Although Red Bellied Pacus are widely considered to be frugivores, they are actually omnivorous, also eating crustaceans and smaller fishes, especially in the dry season. As some of the largest fish in the Amazon, pacu require large amounts of food. They feed in multiple "bite events", with each event containing a number of individual bites, which is similar to the feeding behavior observed in true piranhas (Burkhart, et al., 2002; Fernandes, et al., 2004; Hanke, et al., 2006; Froese and Pauly, 2010).

Cumulative impacts of exotic fish species are resource competition and predation. The result of niche overlap is an ecological havoc, like species extinction. The study revealed that the presence of Pacu in the wild habitat of Vellayani Lake may be due to an accidental release of aquaculture stock. According to local fishermen there had been instances of the presence of these fishes in their catches earlier also, and they used them as food fishes, as riverine pomphret. Recent records of predatory Pacus and piranhas have set the alarm bells ringing for ecological havoc in the Western Ghats biodiversity hotspot (Katwate, et.al, 2012). Red Bellied Pacu is not an invasive fish under natural conditions. But they become invasive as they get released into the natural waters. According to Cagauan and Joshi (2002), the

\section{Volume 4 Issue 12, December 2015}




\section{International Journal of Science and Research (IJSR) \\ ISSN (Online): 2319-7064 \\ Index Copernicus Value (2013): 6.14 | Impact Factor (2014): 5.611}

large Pacu can be disadvantageous to the rice crop by damaging young rice plants, in Philippines. Being an aggressive aquatic plant eater, the fish may be advantageous as a biological control for aquatic weeds and golden apple snail (Cagauan, 2007). The molluscivorous feeding habit of Pacu may have a negative impact on the native edible and economically valuable snails such as Corbicula manilensis, Pila conica, Thiara sp. and Vivipara sp. in Philippines (Cagauan, 2007).

The proliferation of Pacu population in Vellayani Lake will definitely be a threat to the biodiversity of the lake, especially to the ichthyofauna (Mike FishLore, 2012; Lois, 2012; Robert Boumis, 2014), which will have far reaching effects on the livelihood of the local fisher folk.

\section{Conclusion}

The aquarists and game experts usually misidentify Pacus, especially of Piractus genus and the traders import them as vegetarian Piranha, misleading the public into thinking they are Piranhas, creating panic when seen in natural waters. Unlike Piranha, they grow larger in size and eventually become unsuitable for aquaria. This might be one of the reasons for their disposal into natural water bodies. Hence there should be mechanisms to inform the traders and aquarists regarding the correct identity and biology of exotic aquarium fishes

The traders, aquarists and the general public must be made aware of the dangers of exotic species in indigenous natural ecosystems.

In Vellayani Lake, it seems that, a good number of Pacus might have gained entry from an overflowing pond, during rains, where they were cultured for aquarium purpose. If there is a viable population of P. Brachipomus in the lake (it has to be confirmed by further studies), it is a serious matter which should be addressed from a higher level of administration, as these fishes during their intense growth stage may consume the native fishes in large numbers.

\section{References}

[1] Arsenia G. Cagauan, "Red-bellied Pacu in the Philippines Review Paper", Journal of Environmental Science and Management 10(1): 42-47 (June 2007) ISSN 0119-1144, 2007.

[2] Biju Kumar, A and Pramod Kiran, R.B, "Fish Diversity of Vellayani Lake: A Field Guide", Department of Aquatic Biology and Fisheries, University of Kerala, Karyavattom, Thiruvananthapuram, Kerala, 2013.

[3] Burkhart, A., R. Crow, D. Keeley, "Pocket Guide To: The Care and Maintenance of Aquarium Fish", New York, NY: PRC Publishing Ltd, 2002.

[4] Cagauan, A. G. and R. C. Joshi, "Predatory effect of freshwater fishes on golden apple snail Pomacea canaliculata Lam. in screen house conditions", Intl. Rice Res. Notes. International Rice Research Institute, Los Banos, Laguna, Philippines, 2002.

[5] Chatterjee, N. R. \& B. Mazumdar, "Induced breeding of Pacu (Piaractus brachypomus) in captivity with pituitary extract", Aquaculture Asia 14(2): 23. 2009.
[6] Divya Deepak, Raja Swaminathan and V S Basheer and W S Lakra, "Exotic fish found in the Periyar was Pacu", By Express News Service. NBFGR, Kochi unit team, Director, NBFGR, Lucknow. The New Indian Express: 03rd March 2010.

[7] Fernandes, J., R. Lochmann, F. Bocanegra, "Apparent digestible energy and nutrient digestibility coefficients of diet ingredients for pacu Piaractus brachypomus", Journal of the World Aquaculture Society, 35: 237-244, 2004.

[8] Froese, R., D. Pauly, "Fishbase" (On-line). Accessed December 08, 2010 at http://www.fishbase.org/ Summary/SpeciesSummary.php?id=5808. 2010.

[9] Goulding, M., and M.L. Carvalho, "Life history and management of the tambaqui (Colossoma macropomum, Characidae): an important Amazonian food fish", Revista Brasileira de Zoologia 1(2):107-133, 1982.

[10] Hanke, G., M. McNall, J. Roberts, "First records of the yellow bullhead, Ameiurus natalis, a loricariid catfish, Panaque suttonorum, and a silver pacu, Piaractus $c f . P$. brachypomus, in British Columbia", Canadian Field Naturalist, 120/4: 421-427, 2006.

[11]Hill AM, DM Lodge, "Replacement of resident crayfishes by an exotic crayfish: the roles of competition and predation", Ecol. Appl. 9: 678-690. 1999.

[12] Howard, Brian Clark, Brian Clark Howard, "13 Scariest Freshwater Fish: Piranha", National Geographic. Retrieved 4 October 2012.

[13]Innes, W, "Exotic Aquarium Fishes", Neptune, NJ: T.F.H. Publications, Inc., 1966.

[14]Lois 2012. Red Belly Pacu. Fish Lore.com - providing tropical fish tank and aquarium information for freshwater fish and saltwater fish keepers.

[15]Lovera, J, "Food Culture in South America", Westport, CT: Greenwood Publishing Group, 2005.

[16] Machado-Allison, A, Estudio sobre la subfamilia Serrasalminae (Teleostei, Characidae). Prte 1. Estudio comparado de los juveniles de las "cachamas" de Venezuela (generos Colossoma y Piaractus). Acta Biologica Venezuelica 11(3):1-101, 1982.

[17] Mike Fish Lore, "Red Belly Pacu", Fish Lore.com providing tropical fish tank and aquarium information for freshwater fish and saltwater fish keepers, 2012.

[18] Nascimento, A., A. Maria, N. Pessoa, A. Carvalho, "Out-of-season sperm cryopreserved in different media of the Amazonian freshwater fish pirapitinga (Piaractus brachypomus)", Animal Reproduction Science, 118/2: 324-427, 2010.

[19] Padilla, D.K. \& S.L. Williams, "Beyond ballast water: aquarium and ornamental traders as source of invasive species in aquatic ecosystems", Frontiers in Ecology and the Environment 2: 131-138, 2004.

[20] Ramirez-Duarte, W., I. Rondon-Barragan, P. EslavaMocha. Acute toxicity and histopathological alterations of roundup herbicide on "cachama blanca" (Piaractus brachypomus). Pesquisa Veterinaria Brasileira, 28/11: 547-554, 2008.

[21] Rick Spilman, "Beware the Red-Bellied Pacu? TesticleBiting Fish Invading Denmark?”, (On-line) http://www.nbcchicago.com/news/local/Indiana-ManFish-Native-to-South-America-Teeth323436811.html\#ixzz3qgwm8WPH, 2013.

\section{Volume 4 Issue 12, December 2015}




\section{International Journal of Science and Research (IJSR) \\ ISSN (Online): 2319-7064 \\ Index Copernicus Value (2013): 6.14 | Impact Factor (2014): 5.611}

[22] Robert Boumis, 2014. Feeding Tips for Red Belly Pacu. Demand Media. University of Arizona

[23] Ross, S, "The Inland Fishes of Mississippi", Jackson, MS: University Press of Mississippi, 2001.

[24] Ruiz-Carus, R., and S.B, "Davis Register of an exceptionally large red bellied pacu, Piaractus brachypomus (Teleostei, Characidae), in East-Central Florida, with gonad and diet analyses", Florida Scientist 66(3):184-188, 2003.

[25] Sakamoto, K., G. Kaori, T. Smith, "Blood chemistry values of juvenile red pacu (Piaractus brachypomus)", Veterinary Clinical Pathology, 30: 50-52, 2001.

[26] Sandra Bibiana Correa, "Diet shift of Red Belly Pacu Piaractus brachypomus (Cuvier, 1818) (Characiformes: Serrasalmidae), a Neotropical fish, in the Sepik-Ramu River Basin, Papua New Guinea", Neotrop. ichthyol. vol.12 no.4 (On-line version) ISSN 1982-0224, 2015.

[27] Schleser, D, "Piranhas: A Complete Owner's Manual", Hauppauge, NY: Barron's Educational Series, Inc., 1997.

[28] Unmesh, Katwate, D, Apte \& R. Raut, "Invasion in our rivers", Hornbill April-June, 42-45, 2012.

\section{Author Profile}

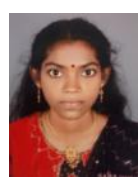

Reenamole.G.R received the B.Sc. degree in Zoology from H.H.M.S.P.B.N.S.S.College for Women, Neeramankara in 2002. B.Ed in Natural Science taken in 2003 from Govt. Anchal College, Kollam. M.Sc. degree in Zoology from Mahatma Gandhi College, Thiruvananthapuram in 2006. M. Phil in Aquatic Biology and Fisheries from the Department of Aquatic Biology \& Fisheries in the University of Kerala, Kariavattom in 2012. All the degrees were received from the University of Kerala, Thiruvananthapuram, India. She has published 5 research papers and designed a text book of "Vellayani Fish Census- a Field Guide and Report" (Author : Dr. A. Biju Kumar \& Dr. Pramod Kiran R.B) published by Dept. of Aquatic Biology and Fisheries, University of Kerala and Supported by Agency of Development of Aquaculture, Kerala (ADAK) 2013. During 2008-2009, she worked as a Project Fellow in Central Marine Fisheries Research Institute in Vizhinjum, Thiruvananthapuram, Kerala, India. She now is doing Ph.D in Zoology at Zoology Research Centre, Department of Zoology, Fatima Mata National College, Kollam, University of Kerala, India.

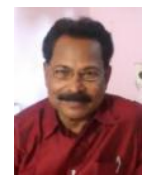

Dr. F. George D'Cruz took his B.sc, M.Sc, and Ph.D degrees from the University of Kerala, India. After Post graduation, he joined Fatima Mata National College (at present a leading Autonomous College in Kerala) under the University of Kerala as Lecturer in 1979. In 1998 he took his Ph.D in Zoology, through Part time Research, while serving as a Professor. In Zoology, his area of specialization was Fisheries and Environmental Toxicology, Biodiversity, Wetland Ecology and Fish Diversity. In 2008, he retired as the HOD of Zoology and at present holds the post of honorary director of the Zoology Research Centre, under the Department of Zoology in the same college. There are about 20 Research papers published in Research Journals and more than 50 scientific papers presented in Seminars, Symposia and other Public functions in his credit. At present he is guiding students for their $\mathrm{Ph} . \mathrm{D}$ in Fish Diversity and Wetland Ecology. He has authored three books and co-authored three other books on various topics like Fisheries, Environmental Biology and Human Evolution, in addition to Scientific Articles in Popular Journals and Print media. There are 16 Radio talks through All India Radio and 15 talks through Radio Benziger, Kollam on various scientific topics under Fisheries, Biodiversity Conservation, Environmental Biology, etc.
Dr. F. George D"eruz"s Contributions as Subject Expert Member in various State Government Bodies like District (Kollam) Monitoring Committee Kerala Forestry Project, Department of Forest (19962002), District (Kollam) Forest Extension and Information Centre, Department of Forest (1996-2002), Committee for Project Formulation and Implementation, Department of Fisheries (20022004), State Council of Educational Research and Training (19992005), Wetland Cell (2004-2006), etc., are noteworthy. He also served as the State Level Programme Co-ordinator of the Kerala State Biodiversity Board in Preparing People"s Biodiversity Register (2009-2011). He had completed 3 projects on Research and Conservation of the State Government Agencies (Department of Fisheries, Department of Forest and Kollam Corporation) 